\title{
The Analysis and the Audit of Enterprises, A New Challenge in Front of Global Crisis Today
}

\author{
Dr. Zaim Korsı ${ }^{1}$ \\ Dr. Hava Mucolları² \\ Msc Emıne Emurllaı ${ }^{3}$ \\ Prof. Dr. Alba Dumi ${ }^{4}$ \\ 1.2 Department of Accounting, UET University" Albania \\ ${ }^{3}$ Political Sciences Department, University of SEEU, Macedonia \\ ${ }^{4}$ Dean of Graduated School, Management Department" Economy Faculty University of Vlore, Albania \\ Email: alba.besi12@gmail.com
}

\section{Doi:10.5901/ajis.2015.v4n3s1p460}

\section{Abstract}

A number of studies have tried to explain SME and how they affect economic growth. These studies have mainly taken the role of SME as an engine of economic growth but connected with perfection of the market and institutional role. While various skeptics question the efficiency of SME and their role speaking in favor of large firms (Biggs, 2002). While many studies have assessed the importance of micro SME in economic growth just in the process of industrialization (Snodgrass and Biggs, 1996). Beck, Demirguc-Kunt and Levine (2005) provide the first evidence on the links between SME, economic growth and poverty reduction, using a new database compiled by Ayyagari, Beck and Demirguc-Kunt (2003). According to their per capita GDP growth and employment in manufacturing report from SME, show a strong positive correlation during the 1990-s.

Keywords: economic growth, efficiency, SME consumer, auditing, GDP correlation.

\section{The Goal of the Paper}

Regressions applied clearly and detailed are controling the opposite of causal relationship and simultaneous bias or prejudice, in the relationship between SME and economic growth. So the results do not necessarily lead to the conclusion that SME do not bring economic growth. In addition, they fail to reject the hypothesis that certainly SME do not show a causal effect on the growth of GDP per capita.

This conclusion is consistent with the view that a large sector of SME is a characteristic of fast-growing economies, but not because of their rapid growth. Beck, Demirguc-Kunt and Levine (2005), also did not reveal any evidence to any link of a large sector of SMEs with faster growth of income for the portion with lower incomes and rapid rates of poverty reduction. The private sector takes place there where this foreign direct investment and domestic investment grow and thrive. Foreign direct investments are directed where business opportunities are greater and barriers to entrepreneurship are small.Then, who are the main factors in determining these investments? First, macroeconomic stability, which certainly plays a role in the central bank, low inflation and political stability. Of course, political stability should be defined first and one of the areas where such ambiguity is what we mean by sustainability and political security.

\section{Introduction}

An obvious study of the rules of the political game and institutional scheme. This stability does not mean that governments should not be changed, because in this case Italy would be developed over the past 60 years, but it means setting clear rules of the political game. Other factors are: a system of appropriate legal and regulatory; of financial markets, employment and real estate, which function well; a good system of property rights and contract enforcement, and low corruption or mechanisms to combat it.What can be done from the standpoint of the government to facilitate domestic investment and foreign direct? The traditional way of developing the theme is to consider investment incentives, financial and fiscal incentives, targeting investors and the sectors to develop competitive advantages of the country. 
These factors should be considered, although should be taken into account because significant distortions are created when using incentive of this nature, but they can be used and used.

The most important activities that can take the government to promote investment are: interference on administrative barriers; intervention to reduce corruption; intervention to promote and develop strong sectors, through a number of indirect mechanisms; and creation of an attractive business environment, which implies factors of production conditions; certainly investment in human capital and infrastructure investments.

\section{Literature Review And Hypotheses}

Meanwhile, there is no firm data on the cross-country relationship between business environment and economic growth. Evidences in industrial level, and firm-level studies consistently show a positive correlation to a competitive business environment with access, entrepreneurship and investment.

$\checkmark$ Report of economic growth and the entry of new firms

Klapper, Laeven and Rajan (2006) demostrate that a means by which business environment affects economic development is the introduction of new firms. Using firm-level data for Western and Eastern Europe, they discover that the input settings, measured as the cost of registering a company, inhibits the creation of new firms, and arrangements to ensure the protection of property rights and access to finance, enhancing so the introduction of new firms.

Moreover, the effect of the strengthened entries appear in a low productivity: the value added per employee in industries usually with "high intake" grow much more slowly in countries with the most severe regulations on introduction. The document also suggests that in some cases a poor business environment can affect the performance of the SME sector because of market limitations and imperfections restrain competition and slow the growth of the firm.

A comparison of Italy and the United Kingdom (UK) illustrates this effect. In Italy, where input costs are $20 \%$ of GNP and the opposite in the UK where they account for 1.4\% of GNP, it has many small firms with slower growth. The problem in Italy is that the SME sector has many old and inefficient firms compared with its counterpart in the UK. Indeed, in Italy they are the biggest firms in the beginning, but grow slowly, while firms in the UK are about twice as large after ten years. These results complement the findings of Beck, Demirguc-Kunt and Levine (2005a) and can provide an explanation of why a large SME are likely not be linked to faster growth, that if the SME sector is large a reflection of inputs and throughputs of small firms.

\section{Problems Encountered by SME}

\subsection{General issues}

Until now the business environment in Albania did not allow the private sector to lead economic growth in the country. This mainly happens because of not enough law enforcement and weak economic infrastructure and social services and administrative inefficient bureaucratic barriers that do not allow to use competitive advantages and benefit from the free trade regime.On the other hand, the lack of competitive advantage is the result of shortcomings in the process of learning of the owner / manager. These deficiencies or gaps in knowledge, the expertise and technical capabilities necessary to generate a-mance discrepancies between actual and desired performance or needed for the firm in a competitive environment.Quite often, education and professional training of entrepreneurs in the past was not related to the business they started. The practice has been the best teacher for them. But today, when competition is strong and growing market opportunities are shrinking, often experience of managers / owners of SMEs is not sufficient to continue business growth.In this context, innovation and development of business management capacity becomes vital for sustainable growth and for establishing business in a high-level that SMEs in Albania focus predominantly on domestic and international competition was lacking. This affects not only the growth opportunities in international markets but should also consider the fact that globalization brings in Albanian international competition at enterprises in their domestic markets. Various international reports, including the Progress Report of the European Commission note that the business environment for SMEs in Albania there were good improvements, particularly with regard to the registration of companies and access to finance.

\subsection{Sample and Data Collections}

However, significant gaps remain in terms of human capital development and technological capacity, hampering the 
ability of Albanian companies to compete properly with SME and EU and thus survive in EU market competition. It is recognized that technological developments in recent years have progressed by leaps galloping and small and medium enterprises in Albania are not longer good enough resources to adapt to these changes. This is reflected in the productivity and quality of products Albanian SME, which compared with those of the EU leaves much to be desired.

The micro - Credit

The micro-credit can be considered as a kind of pre-financing for SMEs. The micro-businesses and family have no access to formal bank loans and as many micro-businesses can not grow significantly, but others can be developed and transferred to SME officially recorded in the future.

In addition, a small number of financial institutions, recently, have started to give loans to SMEs, based on their experience and success in working with them mechanisms for an effective microfinance.By assimilating all the above principles, the final goal of the microfinance sector must be build financially sustainable institutions, which then become a permanent characteristics of the financial system, in other words, who can continue their activity when donor grants or soft loans are no longer possible.

* At this point you can take advantage of microfinance institutions and commercial sources of funding, enabling them to significantly expand their activities and scope. Based on successful practices at the international level, there are a number of elements that are essential in creating effective microfinance institutions:

Using best practices in microfinance project design: it covers a range of issues, including whether the loan is appropriate for group identified how he served the poor, whether using experts in project design phase etc.

* The need to evaluate microfinance against alternative interventions: this includes determination whether microfinance is appropriate and successful, review other strategies that could give better results; and additional interventions.

* Microfinance usually seen in terms of microcredit, even though credit components usually are not as successful for as long as donors do not verify credit access scheme is a real limitation; use of microfinance expertise in the design, implementation and monitoring of projects; creating a performance indicators that follow credit components;

supporting the strengthening of institutions specializing in the provision of financial services; and in the absence of the latter, special support microfinance projects which can lay the foundations for the establishment of permanent financial institutions.

* Because microfinance is different from commercial banking activity, he has to walk to the regulatory and supervisory system of microfinance, as is the removal of the ceiling on interest rates; enabling credit institutions to perform only to lend without licenses and supervision; development of powerful institutions licensed micro-financing; encouraging to establish sound financial procedures and publish them; recognition that microfinance can be provided by a variety of different institutions and the development of an effective supervision of microfinance. Another factor worth mentioning is e-commerce. During recent years have increased in Albania Internet users, especially the younger generation, but still can not speak of a massive use of internet among small and medium producers. Infrastructure generally is considered very poor, limited usage is mainly in Tirana and much less in some of the major districts, while it is almost non-existent in other regions of the country.

\subsubsection{Financial barriers, legal and Institutional ones.}

Becket al. They have shown that higher barriers actually translated into slower growth. Financial barriers to small firms have almost twice the impact on annual growth have are these financial barriers to large businesses. This difference is even more powerful in the case of barriers related to corruption and the legal system, where small firms of "suffer" the consequences about three times more in terms of growth, than large businesses. So not only small businesses reporting higher barriers, but also these barriers more influence in the case of these businesses. 


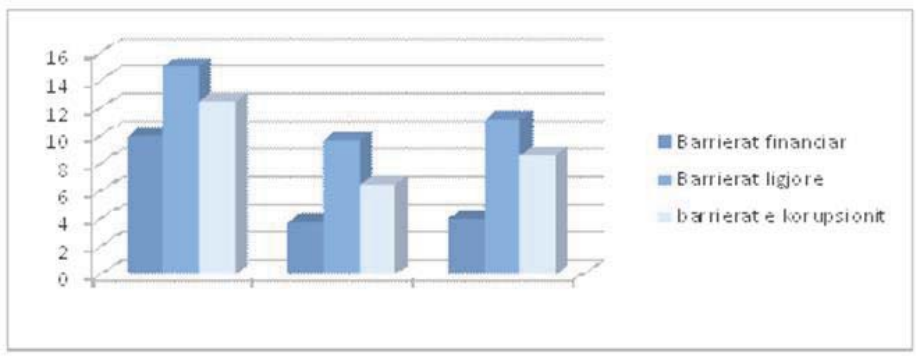

Source: EBRD (2012)

In general, institutional development is the most important characteristic in various countries explains the differences between countries in terms of financial barriers. Firms in countries where higher institutional development report lower financial barriers that firms in countries with lower institutional development. The positive effect of the financial and institutional development can be observed and the use of external funding sources. Better protection of property rights increases external financial resources to small businesses more than large firms, particularly as a result of different impact it has on financing from banks and suppliers.

Eg. Small businesses grow faster in Germany than in Albania, while the opposite occurs for large businesses. Many authors have managed to show that the effect of growth on growth barriers of small businesses is in countries with legal and financial systems of developed countries. And moreover they are very small businesses that benefit most from this institutional development. The effect of financial development and legal barriers and increasing the connection between is noticeably high for small businesses than large ones.

\section{Research Goal}

Many authors suggest that businesses are larger in countries with legal and financial system develop. Also businesses are larger in countries where judicial mechanisms for resolving conflicts and to protect property rights are more developed. These show that the agency problems between foreign investors and domestic contenders make the businesses to be smaller in countries where financial and legal systems are weak. It indicates that programs to promote small businesses can be ineffective and often non-productive time and in places where these systems are not developed, and force small businesses prefer to stay small than grow.

\subsection{Problems faced by Albanian entrepreneurs}

According to a survey I conducted in 60 small businesses in Tirana showed that the biggest problems faced by entrepreneurs are:

a. High tax levels.

b. Unfair competition.

c. The low purchasing power of the population.

d. Difficulties in accessing funding.

e. Lack of cooperation between the various public and private SME support.

f. Unstable legal environment.

g. Lack of qualified human resources

$17 \%$ of respondents rank as the main problem of unfair competition, the top $41 \%$ tax level, and $17 \%$ of the low purchasing power of the population.

\section{Conclusions}

Another shortcoming observed in this study was the fact that SME generally have not asked support from various service providers for businesses.

Thus $46 \%$ of respondents stated that they have never asked the support of various service providers for SME. 
While $28 \%$ said they had asked support from these service providers when their business began to grow or had problems and only $26 \%$ said they had used the services provided before or during the business creation process.

\section{References}

Mohr, L. B. Explaining organizational behavior, San Francisco

Moto A \& S Widow, S. J. "Orientation toward the job and organization", Effects of human resource systems on manufacturing performance and turnover, Academy of Management Journal, VOL. 37, No. 3.

Laursen K., FOSS N. J., New human resource management practices complementarities and the impact on innovation performance, Cambridge Journal of Economics, 27, 2003

De Castri M., "Spazio e organizzazione: verso un nuovo rapporto"

Knittel-Ammerchuber, "The element of success and the strategies and business objectives"

\section{Website}

WWW.NCPPP.ORG/

WWW.LGPA.ORG.

http://www.worldbank.org/ (20.05.2012)

http://www.jobsetc.gc.ca/eng/home-accueil.jsp (20.05.2012)

http://www.bkt.com.al/bktMain.aspx (20.05.2012) 